\title{
Built Environment for Rehabilitation: Case Studies of Selected Juvenile Rehabilitation Centres in Nigeria
}

\author{
Faisal Koko Auwalu and Stephen Nwabunwanne Oluigbo \\ Department of Architecture, Ahmadu Bello University, Zaria, Nigeria \\ *faisal.koko@yahoo.com
}

\begin{abstract}
The character of the built environment of juvenile rehabilitation centres directly impacts on the outcome of the rehabilitation process. The design of such centres should ensure that young offenders who pass through them do not come out more disoriented and hardened. The built environment of juvenile rehabilitation centres should therefore portray rehabilitation rather than retribution. Juvenile rehabilitation centres in Nigeria are in poor conditions and have been described as decaying, and places of punishment. This study was therefore conducted to evaluate the built environment of selected juvenile rehabilitation centres in Nigeria through visual survey, and Likert scale questionnaires containing nine attitude statements. The data was analysed using descriptive account, descriptive statistics, and ANOVA. The result shows that the centres were largely positively perceived with respect to the provision of basic amenities, while aspects relating to the image and visual character of the centres were perceived negatively by majority of the respondents. This suggests a deficit in their design. The result of ANOVA shows that there is no significant difference between respondents of the three juvenile rehabilitation centres (BTIK, BTII and KHRCJ) on four attitude statement while significant differences were obtained on five statements. The character and image of the built environment of these centres needs to be improved in order to give them a more positive outlook which will in turn culminate in more positive outcomes for the young offenders.
\end{abstract}

Keywords: Built Environment, Character, Facilities, Juvenile, Rehabilitation.

\section{INTRODUCTION}

Juvenile delinquency poses a great challenge to the sustainable development of many nations. This is due to the large number of potentially productive children and youths who are incarcerated at one time or another. It is a pressing social problems which has detrimental, emotional, physical and economic effect (Tarolla et al, 2002). The enormity of this challenge calls for a sensitive approach which restores the young offenders to normalcy, rather than one which condemns them to final destruction. While some studies have looked at social, cultural and economic roots of this phenomenon (United Nations, UN, 2003; Hunte, 2006; Green et al, 2008; Simoes et al, 2008), others have advocated the abolition of detention or incarceration of young offenders in favour of community and family-based interventions (Holman and Ziedenberg, 2006) and residential placement (Schubert and Mulvey, 2013). This is due to the unfriendly image and character of many of the juvenile rehabilitation centres, and the fact that many young offenders come out of these centres more hardened. However, while these centres still exist, it is important to pursue interventions that will help them to achieve their objectives. It is therefore vital to make juvenile rehabilitation centres truly rehabilitative rather than punitive. The built environment affects the actions of individuals and their subsequent behaviour and attitudes (Villanueva, 2006), and the character of the built environment has the potential to exert either positive or negative pressure. Therefore, if the goal of juvenile rehabilitation centres is to instil positive attitudes and behaviours, towards reintegration into the society, more attention needs to be given to the character of their built environment. In contrary to this, Burrell (2013) noted that the character of the built environment in many of these centres 
such as, clanging metal doors, limited natural light, cramped spaces, concrete slab beds, among others, projects the feeling of incarceration rather than rehabilitation, thereby making them hostile to youths at a critically vulnerable point in their lives.

In Nigeria, young people aged 10 to 19 years, account for a major proportion of the population (Idris and Ejikeme, 2005). This makes them a resource which cannot be allowed to waste. The juvenile justice system asserts that the rights and needs of juveniles are different from those of adults and should be reflected in the way they are treated (Prison Reform, 2006). This objective is captured in the Children and Young Persons Laws (CYPL) that is already applicable in all the states of Nigeria. About 22 states in Nigeria have so far enacted the Child Rights Law based on the Child Rights Act passed by the Nigerian National Assembly in 2003. In spite of this, the harsh realities remain that a large population of juveniles are detained in adult prisons. For those who are adjudged to be more fortunate to be in juvenile rehabilitation centres, the condition seems not to be much better. The state of incarceration centres in Nigeria has been discussed in a number of studies. Adetula et al (2010) described these centres as decrepit, Tenibiaje (2010) noted that they have become places for punishment and hardening of inmates, while Amnesty International (2008) noted that they exhibit harsh and life threating conditions.

A rehabilitative built environment for juveniles should create the conditions that will engage the inmates and promote the development of positive attitudes and behaviours. In addition to provision of facilities, utilities, and functional built environment, it should have a soothing image and the appropriate sensual characteristics. While many studies have focused on the built environment in urban and rural settings and their effect on juvenile delinquency, it is important to examine the built environment within the rehabilitation centres, especially from the perspective of the young offenders themselves. Schubert and Mulvey (2013) highlighted the importance of seeing the environment of juvenile institutions through the eyes of the adolescents confined there. Their perceptions and attitudes should matter if the goal is truly their reformation. Based on this, the objectives of this study are:

i. To survey the architectural characteristics of built environment in three juvenile rehabilitation centres in Nigeria, and

ii. To survey the perception of the young offenders in these centres about their built environment.

\section{BUILT ENVIRONMENT AND JUVENILE REHABILITATION}

The role of the built environment in behaviour control has long been recognised by environmental psychologists and environment behaviour studies. This is because the built environment can support or inhibit human change (Wener, 2012). It also affects cognitive behaviours of an individual, and an understanding about this relationship can help to determine and predict the activity and behaviour of its users (Cummings, 2012). Positive behavioural interventions seek to prevent juveniles from engaging in negative behaviours by changing the environment in which the behaviours occur (Duda and Utley, 2005). Interventions also aimed at helping juveniles to acquire the behavioural and social skills that they will need to succeed in an inclusive environment (Choutka et al, 2004; Lane et al, 2004). The built environment comprises of infrastructural elements, utilities, and all other structures created by humans (McClure and Bartuska, 2007). It is the integrated built context in which individuals live, and it affects the attitude and behaviour of people in many ways (Mazumdar, 2000), and has a significant influence on the development of individuals and their activities and social interactions. Good environmental conditions engender normal development, while bad environmental conditions adversely affect development (Malekpour, 2007). According to the United Nations (UN, 1990), one of the ways of reducing juvenile delinquency is by altering the physical features of the environment through architectural and landscape planning and providing opportunities to engage young people's interest. 
The built environment for juvenile rehabilitation centres is here discussed under the following:

i. Location and site planning;

ii. Spatial organisation;

iii. Provision of amenities;

iv. Supervision and security;

v. Visual character; and

vi. Psychological character.

\subsection{LOCATION AND SITE PLANNING}

Although barriers may be necessary to maintain security in juvenile rehabilitation centres, Gendreau and Keyes (2001) noted that rehabilitation centres are public social institutions which should be integrated in the community and blend with the surrounding built environment. This is important in order not to disconnect the young offenders from the environment into which they will be discharged. The site design of the centres should aim at deinstitutionalizing them through the creation of a normal and modern built environment that aids rehabilitation of delinquents. It should also allow the physical contact with the outside for individual and group activities (Mcmillen and Justice Planners International JPI, 2005).

\subsection{SPATIAL ORGANIZATION}

The Spatial organizations of a juvenile rehabilitation centre is best organized around spaces that allows for surveillance, optimum utilization of daylight, and ventilation (Waid and Clement, 2001). The layout should have similar functions grouped into functional cluster or arranged in linear sequence with appropriate access to outdoor spaces that must be easily accessible to the users with segregation for privacy. With these requirements, the best form of spatial organization would be a centralized or courtyard form of organization. There is also the need for changing spatial scale and shapes that reflect those normally encountered in daily experience (Mcmillen and JPI, 2005). The central spaces or courtyards when beautified would also serve as good view from different sections of the facility thereby improving the rehabilitation process.

\subsection{PROVISION OF AMENITIES}

Placement in juvenile rehabilitation centres deprives young offenders of the facilities such as school, sports, and other activities which they were used to at their homes. These deprivations should be ameliorated by the rehabilitation centres. Jones (2008) noted the importance of satisfying needs to behavioural interventions. The fulfilling of an individual's needs results in confidence and happiness, but when the need is not fulfilled, the result is frustration. It is therefore important that the built environment of juvenile rehabilitation centres be targeted at providing the basic amenities to ensure some level of fulfilment in order to prevent frustration. Therefore, the built environment should be versatile and less restrictive in order to afford opportunities for various activities. It should provide conditions for activities that promote positive behaviours and reduce indulgence in negative ones. Sports, recreation and a variety of physical activities should be readily available to discourage idleness and promote healthy social interaction (Mcmillen and JPI, 2005).

\subsection{SUPERVISION AND SECURITY}

The character of the built environment in juvenile rehabilitation centres should play both a conducive and restrictive role (Cummings, 2012). While supervision and security is essential in juvenile rehabilitation centres, an effective design of the built environment should maximize freedom, mobility and flexibility (Marmot, 2002). Circulation corridors should be open and visible, with minimum levels and blind spots in order to provide clear sightlines within the facility (Waid and Clements, 2001; Griffin and Hepburn, 2013). This will reduce the need for direct supervision and promote unobtrusive supervision which enhances the non-institutional nature and encourages normal behaviour (Mcmillen and JPI, 2005). This does not eliminate the need for direct supervision. This is because direct supervision is an effective way to work towards delinquents' respect, and promotes constant and direct interaction between the staff and the young offenders (Akinci, 2012). 


\subsection{VISUAL CHARACTER}

The first impression communicated to anyone who approaches a building is through visual characteristics or aesthetics, and it is widely understood that first impression is always lasting. Therefore, the elimination of the stereotypical intimidating image of punishment and incarceration is vital for the design of a successful juvenile rehabilitation centre (Atlas and Dunham, 1990). This will reduce the feeling of condemnation which a juvenile feel when being taken to such facilities. Mcmillen and JPI, (2005) noted the importance of a familiar and comfortable surroundings in order to minimize negative reactions such as aggressive behaviour and territorial expressions. The built environment of juvenile rehabilitation centres should therefore strive to achieve home-like characteristics. The architectural character of rehabilitation centre should be inspiring providing clear views from nature, with the use of normalized materials, soft texture and colours (Crowe, 2000). It should also foster an attitude of self-esteem (Reaper and Kamenev, 2004). Other desirable characteristics include: Light colours, decorative accents, spatial openness, and visual variety.

\subsection{PSYCHOLOGICAL CHARACTERISTICS}

Holman and Ziedenberg (2006) noted that the detention of young offenders in facilities with the semblance of prisons should be discouraged. Burrell (2013:2) noted that the "removal of a child from the home, even for a brief period, is itself a traumatic event. Loss of liberty, personal identity, and the familiar landscape of daily life is a frightening, disorienting, and life-changing event...especially for young people. Institutional placement deprives young offenders from support from family and friends... who would otherwise help them to cope with anxiety and uncertainty". This traumatic picture painted by Burrell should be diffused through the creation of a soothing built environment that attempts at replacing these losses and supporting the young offenders. Design of juvenile centres could benefit from a connection with family and kin where possible. This may be projected through the use of materials which allows the offenders views of the surrounding community and vice versa (Grant, 2014). According to McMillen and JPI (2005), appropriate design of juvenile rehabilitation centres should create spaces that are responsive to residents' and staff perceptions and behaviours, and the demands of daily programming. Such spaces, contribute in encouraging positive responses and cooperation, and a willingness to take advantage of opportunities. This will reduce the feeling of incarceration and promote connection with the community (Grant, 2014).

\section{METHOD OF STUDY}

In Nigeria, the Borstal institutions and Remand Centre Act, Cap.B11 LTN 2004 recognises Borstal and Remand Centres as federal juvenile correctional institutions. However, states and local governments are authorised to set up similar institution after necessary approval (Laws of Federation of Nigeria, 2004). There are currently only three Borstal institutions in Nigeria, and these are administered by the Nigerian Prisons Service. The first at Kaduna, the second at Ilorin and the third at Abeokuta. All three only have only male offenders (www.prisons.gov.ng). Based on this, Borstal Training Institution, Kaduna (BTIK), Borstal Training Institution, Ilorin (BTII) which are the two fully functional ones were selected purposively. Also Kafin-Hausa Reformatory Centre (KHRCJ), which is owned by the Jigawa state government was selected as a third case. This also houses only male offenders. BTIK was established in 1960, but formally began operation in 1962. BTII was previously known as the Child Centre and was originally built by the Kwara state government but later handed to the Nigeria Prison Service. The institution was commissioned on the 29th December, 2005. KHRCJ was established in the 80s. As at the time of survey, BTIK has a total of 392 young offenders, BTII had 207, while KHRCJ had 25. Data was collected through visual survey and questionnaire survey.

The visual survey examined the built environment of the centres based on characteristics identified in literature as desirable for juvenile rehabilitation centres. The checklist for the visual survey consists of the following 
Location, site planning, spatial organisation, provision of amenities, security and supervision, visual character, and psychological character. The data obtained through visual survey were analysed descriptively based on requirements for juvenile facilities, and issues raised on the above characteristics as contained in the literature review.

Two hundred and thirty-nine (239) questionnaire were administered on the juveniles in the three juvenile rehabilitation centres. Sample size was determined based on Fisher's Formula with known population size as follows:

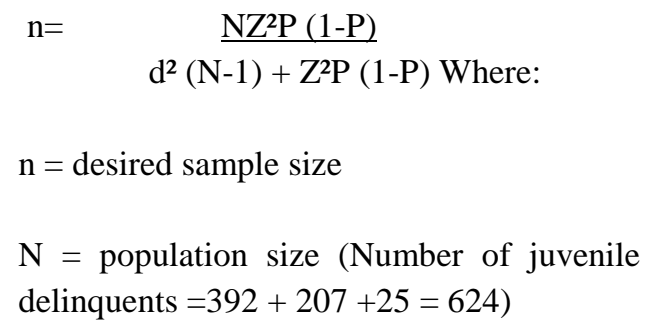

Using Proportionate allocation for each rehabilitation centre, that is Kaduna, Ilorin and Jigawa.

The number for each rehabilitation centre is as follows.

Kaduna $=392 / 624 \times 239=150$ Juvenile delinquents

Ilorin $=207 / 624 \times 239=79$ juvenile Delinquents

Jigawa $=25 / 624 \times 239=10$ juvenile delinquents
One hundred and fifty (150) questionnaires were administered at BTIK, seventy-nine (79) questionnaires administered at BTII and ten (10) questionnaires administered at KHRCJ. Systematic sampling was used, that is selection of the nth subject at each rehabilitation centre, where $\mathrm{n}$ is the number determined by dividing the population at each rehabilitation centre by the required sample size.

The questionnaire contained attitude scaling question placed on a continuum of agreement or disagreement as follows: Strongly Disagree (SD) $=1, \operatorname{Disagree}(\mathrm{D})=2, \operatorname{Neutral}(\mathrm{N})=3, \operatorname{Agree}(\mathrm{A})$ $=4$, and Strongly Agree $(\mathrm{SA})=5$. The five-point scale is simple and common, and is suitable considering the ages and level of education of the respondents. It also allows for a middle or zero point which provides an option for respondents who neither agreed nor disagreed, or had no opinion on the statement (Osuala, 2005). The questions were used to elicit data regarding juvenile perception of their built environment. The collected data was subjected to descriptive analysis to obtain frequencies, percentages, and means using SPSS software. Also, Analysis of Variance (ANOVA) was conducted in order to examine the differences between the means at the three juvenile rehabilitation centres.

\section{RESULTS AND DISCUSSION}

This section is divided into three main parts. The first part discusses the result of data obtained through visual survey, while the second part discusses the result of questionnaire survey. The third part triangulates and discusses the results in relation to existing literature.

\subsection{VISUAL SURVEY RESULTS}

The result of the visual survey is discussed under six headings which are; location and site planning, spatial organisation, provision of amenities, supervision and security, visual character, and psychological characteristics.

\subsubsection{Location and Site Planning}

The visual survey shows that the three juvenile rehabilitation centres (BTIK, BTII, and KHRCJ) are isolated from the surrounding communities and fenced with block walls. Also, the buildings 
in the three centres were largely rectangular blocks with the semblance of classroom blocks in Nigerian schools.

\subsubsection{Spatial Organisation}

Visual survey shows that the buildings at BTIK are laid out around a central courtyard with no clear evidence of zoning or clusters (Fig. 1). KHRCJ on the other hand has a dispersed and clustered layout with facilities organised in clusters based on their functional relationships (Fig. 3). BTII is of a single cluster of closely packed buildings (Fig. 2).

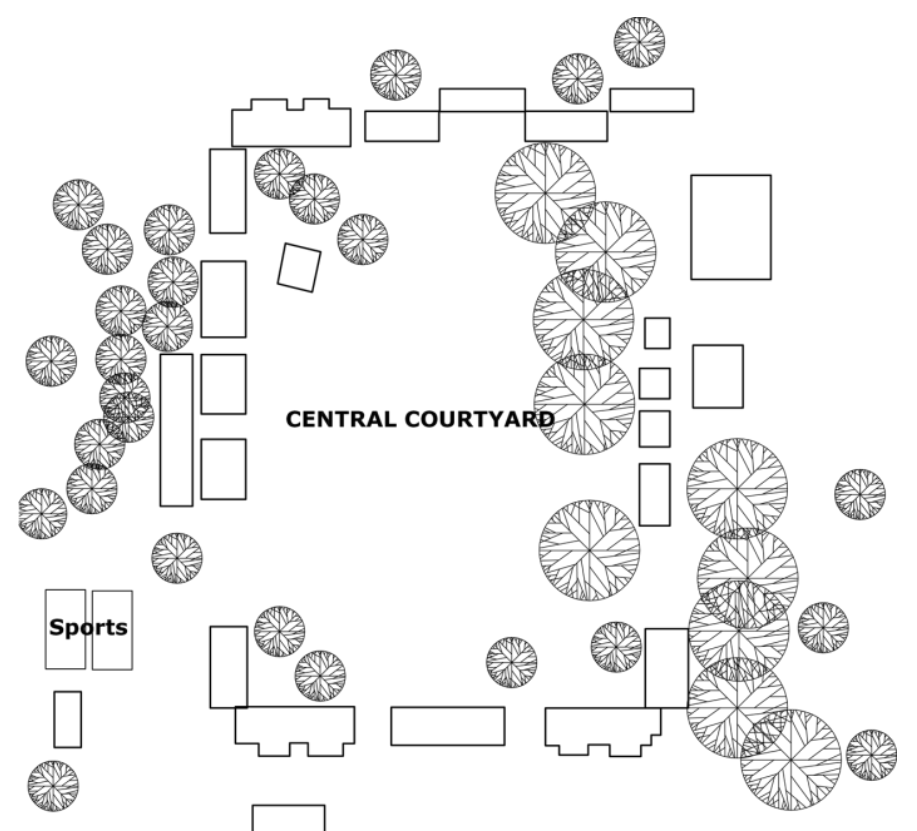

Fig. 1: Layout of Borstal Training Institution, Kaduna (BTIK).

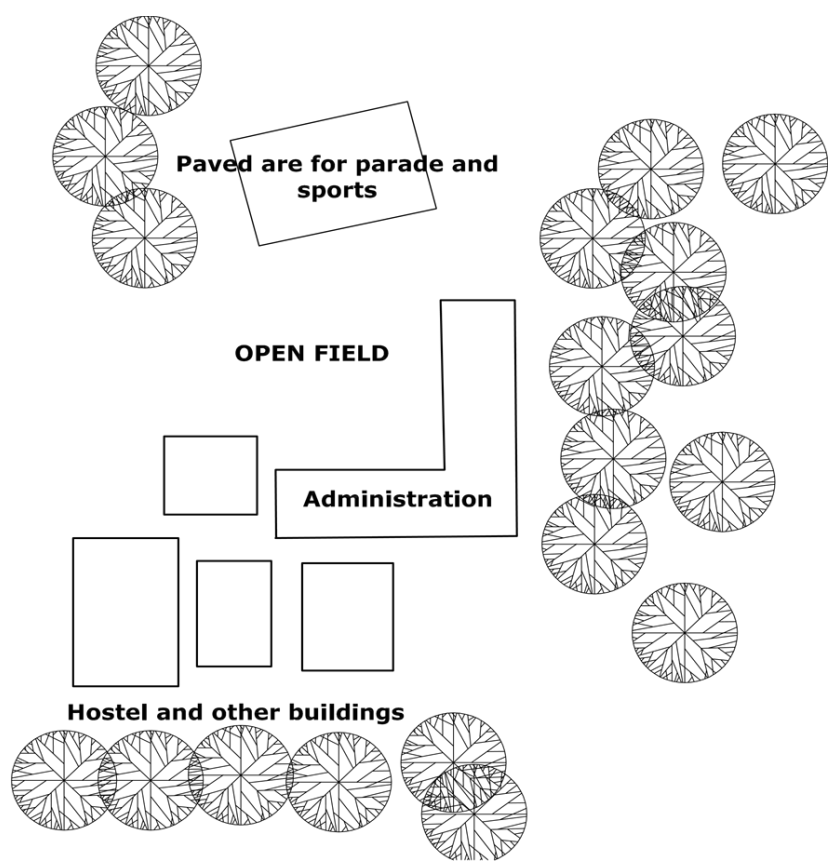

Fig. 2: Layout of Borstal Training Institution, Ilorin (BTII). 


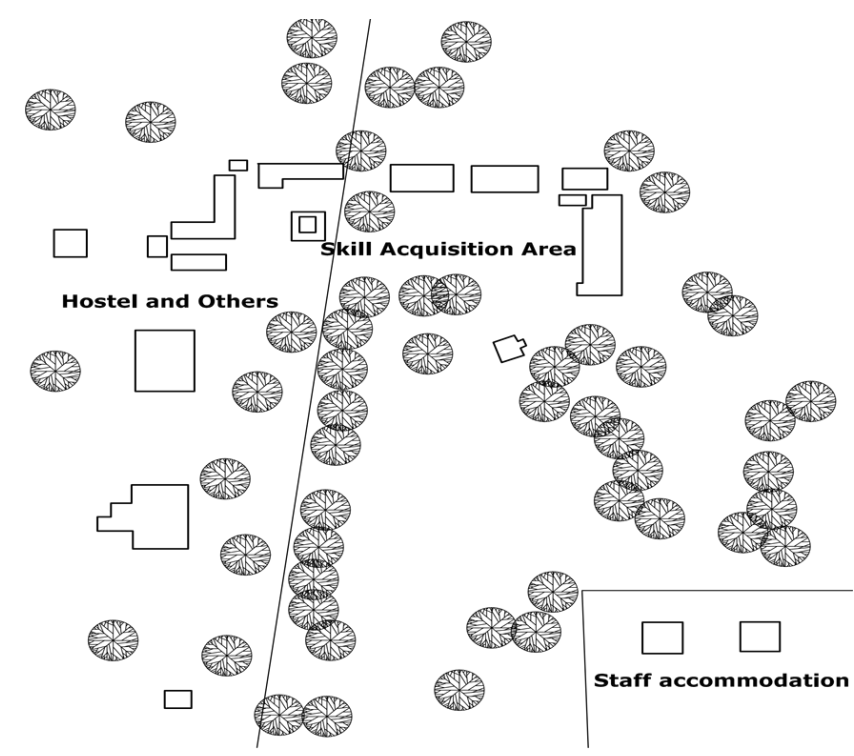

Fig. 3: Layout of Kafin-Hausa Reformatory Centre, Jigawa (KHRCJ).

\subsubsection{Provision of Amenities}

Facilities at BTIK can be classified into administrative, assembly hall, hostel accommodation, educational and skill acquisition, religious (church and mosque), medical, dinning and sports and recreational facilities. The sports and recreational facilities are however limited to volleyball courts, and a football pitch. Facilities at BTII are even more limited. These are the administrative/educational building, skill acquisition building, dining hall, and hostels. There is no religious building, and an open parade ground in front of the administrative building doubles as the only facility for sports and recreation. At KHRCJ,

\subsubsection{Visual Character}

Most of the buildings in the three juvenile rehabilitation centres are rectangular buildings with the semblance of classroom blocks in Nigeria. These were fenced with block walls. The buildings are of single floor, except for the administrative block at BTIK which is of two floors. The three centres were painted in shades of green and yellow. These are the colours of the Nigerian Prison Service. available facilities include: administrative, educational, skill acquisition, staff accommodation, hostels, cells, laundry, mosque, dining, and the only visible sports and recreational facility which is a basketball court, though there is ample open space which was used for football and other activities.

\subsubsection{Supervision and Security}

The buildings in BTIK and KHRCJ are well spaced out with few blind spots, and watch towers. BTII on the other hand is of a single cluster of closely packed buildings which creates more blind spots. There is also no watch tower.

\subsubsection{Psychological Characteristics}

The three juvenile rehabilitation centres are isolated from the communities, fenced with block walls and painted with the colours of the Nigerian Prison Service thereby projecting the image of incarceration. These walls also prevented visual contact with the environment outside the centres. A summary of visual survey result is given in Table 1 below. 
Table 1: Summary of Visual Survey Result

\begin{tabular}{|c|c|c|c|c|}
\hline Characteristics & Requirements & BTIK & BTII & KHRCJ \\
\hline \multirow[t]{2}{*}{$\begin{array}{c}\text { Location and Site } \\
\text { Planning }\end{array}$} & $\begin{array}{l}\text { Integrate into } \\
\text { community }\end{array}$ & $\begin{array}{l}\text { Isolated from host } \\
\text { community }\end{array}$ & $\begin{array}{l}\text { Isolated from } \\
\text { host community }\end{array}$ & $\begin{array}{l}\text { Isolated from } \\
\text { host community }\end{array}$ \\
\hline & $\begin{array}{l}\text { Deinstitutionalized } \\
\text { and normal built } \\
\text { environment }\end{array}$ & $\begin{array}{l}\text { Environment } \\
\text { appears } \\
\text { institutional }\end{array}$ & $\begin{array}{l}\text { Environment } \\
\text { appears less } \\
\text { institutional }\end{array}$ & $\begin{array}{l}\text { Environment } \\
\text { appears } \\
\text { institutional }\end{array}$ \\
\hline \multirow[t]{2}{*}{ Spatial Organisation } & $\begin{array}{ll}\text { Allow for } & \text { for } \\
\text { surveillance } & \end{array}$ & $\begin{array}{l}\text { Central courtyard } \\
\text { plan which aids } \\
\text { supervision and } \\
\text { surveillance }\end{array}$ & $\begin{array}{l}\text { Difficulty in } \\
\text { surveillance }\end{array}$ & $\begin{array}{l}\text { Separate } \\
\text { surveillance } \\
\text { point required } \\
\text { for the different } \\
\text { clusters }\end{array}$ \\
\hline & $\begin{array}{l}\text { Functional clusters } \\
\text { or linear sequence }\end{array}$ & $\begin{array}{l}\text { Central } \text { courtyard } \\
\text { with no clear } \\
\text { evidence } \\
\text { functional clusters }\end{array}$ & $\begin{array}{lr}\text { Sing cluster } \\
\text { with no } \\
\text { separation of } \\
\text { functions }\end{array}$ & $\begin{array}{l}\text { Presence of } \\
\text { functional } \\
\text { clusters }\end{array}$ \\
\hline \multirow[t]{3}{*}{ Provision of Amenities } & $\begin{array}{l}\text { Sports and } \\
\text { recreational } \\
\text { facilities }\end{array}$ & $\begin{array}{l}\text { Football and } \\
\text { volleyball pitches }\end{array}$ & $\begin{array}{l}\text { No sports and } \\
\text { recreational } \\
\text { facilities }\end{array}$ & $\begin{array}{l}\text { Un-demarcated } \\
\text { open space used } \\
\text { for football }\end{array}$ \\
\hline & $\begin{array}{l}\text { Skill acquisition } \\
\text { facilities }\end{array}$ & $\begin{array}{l}\text { Skill acquisition } \\
\text { facilities were } \\
\text { provided }\end{array}$ & $\begin{array}{l}\text { Skill } \\
\text { acquisition } \\
\text { facilities were } \\
\text { provided }\end{array}$ & $\begin{array}{l}\text { Skill acquisition } \\
\text { facilities were } \\
\text { provided }\end{array}$ \\
\hline & Religious facilities & $\begin{array}{l}\text { Presence of a } \\
\text { mosque }\end{array}$ & $\begin{array}{l}\text { No religious } \\
\text { buildings }\end{array}$ & $\begin{array}{l}\text { Presence of a } \\
\text { mosque }\end{array}$ \\
\hline \multirow[t]{2}{*}{ Supervision and Security } & Avoid blind spots & $\begin{array}{l}\text { Central courtyard } \\
\text { reduces blind spots }\end{array}$ & $\begin{array}{l}\text { Closely-built } \\
\text { single cluster } \\
\text { with blind spots }\end{array}$ & $\begin{array}{l}\text { Openness } \\
\text { reduces blind } \\
\text { spots }\end{array}$ \\
\hline & $\begin{array}{l}\text { Promote freedom } \\
\text { and unobtrusive } \\
\text { supervision }\end{array}$ & $\begin{array}{l}\text { Obtrusive through } \\
\text { use of watch- } \\
\text { towers }\end{array}$ & $\begin{array}{l}\text { Obtrusive } \\
\text { through use of } \\
\text { watch-towers }\end{array}$ & No watchtower \\
\hline \multirow[t]{3}{*}{ Visual Character } & $\begin{array}{l}\text { Inspiring and } \\
\text { foster self esteem }\end{array}$ & $\begin{array}{l}\text { Rectangular } \\
\text { buildings with the } \\
\text { semblance of } \\
\text { classroom blocks }\end{array}$ & $\begin{array}{l}\text { Rectangular } \\
\text { buildings with } \\
\text { the semblance } \\
\text { of classroom } \\
\text { blocks }\end{array}$ & $\begin{array}{l}\text { Rectangular } \\
\text { buildings with } \\
\text { the semblance of } \\
\text { classroom blocks }\end{array}$ \\
\hline & $\begin{array}{l}\text { Familiar, home- } \\
\text { like comfortable } \\
\text { environment }\end{array}$ & $\begin{array}{l}\text { Rectangular } \\
\text { buildings with the } \\
\text { semblance of } \\
\text { classroom blocks }\end{array}$ & $\begin{array}{l}\text { Rectangular } \\
\text { buildings with } \\
\text { the semblance } \\
\text { of classroom } \\
\text { blocks }\end{array}$ & $\begin{array}{l}\text { Rectangular } \\
\text { buildings with } \\
\text { the semblance of } \\
\text { classroom blocks }\end{array}$ \\
\hline & $\begin{array}{l}\text { Eliminate image of } \\
\text { incarceration and } \\
\text { punishment }\end{array}$ & $\begin{array}{l}\text { fenced with solid } \\
\text { blocks which } \\
\text { promotes image of } \\
\text { incarceration }\end{array}$ & $\begin{array}{l}\text { fenced with } \\
\text { solid blocks } \\
\text { which promotes } \\
\text { image of } \\
\text { incarceration }\end{array}$ & $\begin{array}{l}\text { fenced with solid } \\
\text { blocks which } \\
\text { promotes image } \\
\text { of incarceration }\end{array}$ \\
\hline \multirow[t]{2}{*}{$\begin{array}{c}\text { Psychological } \\
\text { Characteristics }\end{array}$} & $\begin{array}{l}\text { Integrate with } \\
\text { community }\end{array}$ & $\begin{array}{l}\text { located away from } \\
\text { host community }\end{array}$ & $\begin{array}{l}\text { located away } \\
\text { from host } \\
\text { community }\end{array}$ & $\begin{array}{lr}\text { located away } \\
\text { from host } \\
\text { community }\end{array}$ \\
\hline & $\begin{array}{l}\text { Reduce image of } \\
\text { incarceration }\end{array}$ & $\begin{array}{l}\text { fenced with solid } \\
\text { blocks which } \\
\text { promotes image of } \\
\text { incarceration }\end{array}$ & $\begin{array}{l}\text { fenced with } \\
\text { solid blocks } \\
\text { which promotes } \\
\text { image of } \\
\text { incarceration }\end{array}$ & $\begin{array}{l}\text { fenced with solid } \\
\text { blocks which } \\
\text { promotes image } \\
\text { of incarceration }\end{array}$ \\
\hline
\end{tabular}




\subsection{QUESTIONNAIRE SURVEY RESULTS}

Questionnaire survey result is discussed under six headings which are; location and site planning, spatial organisation, provision of amenities, supervision and security, visual character, and psychological characteristics.

\subsubsection{Location and Site Planning}

Majority of the respondents from the three rehabilitation centres, $79.33 \%$ from BTIK, $78.75 \%$ from BTII and $80 \%$ from KHRCJ agreed that the location of the facility makes them feel isolated and incarcerated. (Table 2). Mean scores for this attitude statement were 3.91, 3.87, and 4.00 for BTIK, BTII and KHRCJ respectively, with a cumulative score of 3.90 (Table 3).

Table 2: Level of Agreement of Respondents with Attitude Statements

\begin{tabular}{l|l|l|l|l}
\hline Statements & BTIK & BTII & KHRCJ & Cumulative \\
\hline The facility is isolated from the community and promotes & 119 & 63 & 08 & 190 \\
the image of punishment and incarceration & $(79.33 \%)$ & $(79.75 \%)$ & $(80.00 \%)$ & $(79.50 \%)$ \\
\hline The landscaping of their respective centres were pleasing & 73 & 63 & 02 & 138 \\
and encouraged outdoor activities & $(48.66 \%)$ & $(79.75 \%)$ & $(20.00 \%)$ & $(57.74 \%)$ \\
\hline The layout of facilities and circulation system encourages & 88 & 52 & 01 & 141 \\
active participation & $(58.66 \%)$ & $(65.83 \%)$ & $(10 \%)$ & $(58.99 \%)$ \\
\hline Adequate sports and recreational facilities are provided to & 116 & 29 & 03 & 160 \\
prevent idleness and anti-social behaviour & $(77.34 \%)$ & $(51.89 \%)$ & $(30 \%)$ & $(66.94 \%)$ \\
\hline The presence of common facilities (dayrooms, religious & 103 & 26 & 09 & 138 \\
facilities etc.) encourages healthy social interaction & $(68.67 \%)$ & $(35.44 \%)$ & $(90 \%)$ & $(57.74 \%)$ \\
\hline I feel normal being watched by guard stationed all over the & 61 & 33 & 02 & 96 \\
centre & $(40.67 \%)$ & $(41.77 \%)$ & $(20.00 \%)$ & $(41.84 \%)$ \\
\hline The visual characteristic of the building is pleasing and & 56 & 43 & 05 & 104 \\
inspiring & $(38.50 \%)$ & $(54.43 \%)$ & $(50.00 \%)$ & $(43.51 \%)$ \\
\hline The interior colours of the buildings are not pleasing & 75 & 46 & 04 & 125 \\
& $(50 \%)$ & $(57.23 \%)$ & $(40 \%)$ & $(53.2 \%)$ \\
\hline The design promotes the image of incarceration and & 92 & 76 & 10 & 163 \\
contributes to depression & $(61.32 \%)$ & $(77.22 \%)$ & $(100 \%)$ & $(68.20 \%)$ \\
\hline
\end{tabular}

Table 3: Mean Scores of Respondents' Evaluation of the Built Environment of Juvenile Rehabilitation Centres

\begin{tabular}{l|l|l|l|l}
\hline Statements & BTIK & BTII & KHRCJ & Cumulative \\
\hline $\begin{array}{l}\text { The facility is isolated from the community and promotes the } \\
\text { image of punishment and incarceration }\end{array}$ & 3.91 & 3.87 & 4.00 & 3.90 \\
\hline $\begin{array}{l}\text { The landscaping of their respective centres were pleasing and } \\
\text { encouraged outdoor activities }\end{array}$ & 3.15 & 3.91 & 2.20 & 3.36 \\
\hline $\begin{array}{l}\text { The layout of facilities and circulation system encourages active } \\
\text { participation }\end{array}$ & 3.37 & 3.48 & 2.20 & 3.36 \\
\hline $\begin{array}{l}\text { Adequate sports and recreational facilities are provided to } \\
\text { Prevent idleness and anti-social behaviour }\end{array}$ & 4.04 & 3.21 & 2.60 & 3.70 \\
\hline $\begin{array}{l}\text { The presence of common facilities (dayrooms, religious facilities } \\
\text { etc.) encourages healthy social interaction }\end{array}$ & 3.68 & 2.50 & 4.60 & 3.33 \\
\hline I feel normal being watched by guard stationed all over the centre & 2.77 & 2.81 & 2.10 & 2.76 \\
\hline $\begin{array}{l}\text { The visual characteristic of the building is pleasing and inspiring } \\
\text { The interior colours of the buildings are not pleasing }\end{array}$ & 2.81 & 3.19 & 3.30 & 2.95 \\
\hline $\begin{array}{l}\text { The design promotes the image of incarceration and contributes to } \\
\text { depression }\end{array}$ & 3.53 & 3.90 & 4.80 & 3.71 \\
\hline
\end{tabular}


At BTIK $48.66 \%$ agreed with the statement that the landscaping of their respective centres were pleasing and encouraged outdoor activities. At BTII, and KHRCJ the agreement was $79.75 \%$ and $20 \%$ respectively (Table 2). Mean scores for this attitude statement were 3.15, 3.91, and 2.20 for BTIK, BTII and KHRCJ respectively, with a cumulative score of 3.36 (Table 3 ).

\subsubsection{Spatial Organisation}

Majority of the respondents from BTIK $(58.66 \%)$ and BTII $(65.83 \%)$ agreed with the statement that the layout of facilities and circulation system encourages active participation. However, only $10 \%$ of the respondents from KHRCJ agreed with the statement (Table 2). Mean scores for this attitude statement were $3.37,3.48$, and 2.20 for BTIK, BTII and KHRCJ respectively, with a cumulative score of 3.36 (Table 3 ).

\subsubsection{Provision of Amenities}

Majority of the respondents at BTIK $77.34 \%$ agreed that adequate sports and recreational facilities were provided, and helps in preventing idleness and anti-social behaviour within the centre. At BTII, there was little difference between those that agreed $(51.89 \%)$ and those that disagreed $(40.42 \%)$ with the statement, while at KHRCJ, only $30 \%$ of the respondents agreed with the statement (Table 2). Mean scores for this attitude statement were 4.04, 3.21, and 2.60 for BTIK, BTII and KHRCJ respectively, with a cumulative score of 3.70 (Table 3 ). Also, majority of the respondents in BTIK $(68.67 \%)$ agreed with the statement that the presence of common facilities (day rooms, religious facilities) encourages healthy social interaction. At KHRCJ, 90\% of the respondents agreed with the statement, while only $35.44 \%$ at BTII agreed with the statement (Table 2). Mean scores for this attitude statement were 3.68, 2.50, and 4.60 for BTIK, BTII and KHRCJ respectively, with a cumulative score of 3.33 (Table 3 ).

\subsubsection{Supervision and Security}

At BTIK, $40.67 \%$ agreed with the statement that they felt normal being watched by guard stationed all over the centre. While at BTII and KHRCJ the figures were $41.77 \%$ and $20.00 \%$ respectively (Table 2). Mean scores for this attitude statement were 2.77, 2.81, and 2.20 for BTIK, BTII and KHRCJ respectively, with a cumulative score of 2.76 (Table 3).

\subsubsection{Visual Characteristics of Building}

At BTIK $38.50 \%$ of respondents agreed with the statement that the visual characteristics of the buildings were pleasing and inspiring, while at BTII, the $54.43 \%$ agreed. At KHRCJ, $50 \%$ of respondents agreed with the statement (Table 2). Mean scores for this attitude statement were 2.81, 3.19, and 3.30 for BTIK, BTII and KHRCJ respectively, with a cumulative score of 2.95 (Table 3). With regards to the colour of the buildings, at BTIK $50 \%$ of respondents agreed with the statement that the interior colours of the buildings were not pleasing, while at BTII, $57.23 \%$ agreed. At KHRCJ, $40 \%$ of respondents agreed with the statement (Table 2). Mean scores for this attitude statement were 3.15, 3.35, and 3.30 for BTIK, BTII and KHRCJ respectively, with a cumulative score of 3.36 (Table 3 ).

\subsubsection{Psychological Characteristics}

Majority of the respondents from BTIK $(61.32 \%)$ and BTII $(77.22 \%)$ agreed with the statement that the design promotes the image of incarceration thereby contributing to depression. Similarly, at KHRCJ, all the respondents (100\%) agreed with the statement (Table 2). Mean scores for this attitude statement were 3.53, 3.90, and 4.80 for BTIK, BTII and KHRCJ respectively, with a cumulative score of 3.71 (Table 3 ).

\subsubsection{Variance in Respondents' Perception}

The result of ANOVA shows that there is no significant difference between respondents of the three juvenile rehabilitation centres (BTIK, BTII and KHRCJ) on the statement that the facility is isolated and promotes image of incarceration with a $\mathrm{p}$ value of $0.663>0.05$ (Table 5). This was also same for three other statements: I feel normal when being watched by guard, $p=0.247$; the interior colours are pleasing, $p=0.930$; and the design does not allow view outside, $\mathrm{p}=0.282$. There were however significant differences on five statements; the landscape is pleasing and encourages outdoor activities, $\mathrm{p}=0.000$; layout of facility encourages active participation, $\mathrm{p}=$ 0.008 ; adequate sports and recreational facilities are provided, $\mathrm{p}=0.000$; adequate common facilities are provided to encourage social interaction, $\mathrm{p}=0.000 ;$ and the visual characteristics of the facility is pleasing, $\mathrm{p}=$ 0.016 respectively (Table 4$)$. 
Table 4: Analysis of Variance for BTIK, BTII and KHRCJ

\begin{tabular}{|c|c|c|c|c|c|c|}
\hline & & $\begin{array}{l}\text { Sum of } \\
\text { Squares }\end{array}$ & df & $\begin{array}{l}\text { Mean } \\
\text { Square }\end{array}$ & $\mathbf{F}$ & Sig. \\
\hline \multirow{3}{*}{$\begin{array}{c}\text { Facility is isolated and } \\
\text { promotes image of } \\
\text { incarceration }\end{array}$} & Between Groups & 1.119 & 2 & .559 & .411 & .663 \\
\hline & Within Groups & 315.673 & 232 & 1.361 & & \\
\hline & Total & 316.791 & 234 & & & \\
\hline \multirow{3}{*}{$\begin{array}{c}\text { Landscape is pleasing and } \\
\text { encourages outdoor } \\
\text { activities }\end{array}$} & Between Groups & 35.283 & 2 & 17.641 & 11.271 & .000 \\
\hline & Within Groups & 358.441 & 229 & 1.565 & & \\
\hline & Total & 393.724 & 231 & & & \\
\hline \multirow{3}{*}{$\begin{array}{c}\text { Layout of facility } \\
\text { encourages active } \\
\text { participation }\end{array}$} & Between Groups & 16.791 & 2 & 8.395 & 4.944 & .008 \\
\hline & Within Groups & 388.860 & 229 & 1.698 & & \\
\hline & Total & 405.651 & 231 & & & \\
\hline \multirow{3}{*}{$\begin{array}{c}\text { Adequate sports and } \\
\text { recreational facilities are } \\
\text { provided }\end{array}$} & Between Groups & 62.237 & 2 & 31.118 & 19.798 & .000 \\
\hline & Within Groups & 363.080 & 231 & 1.572 & & \\
\hline & Total & 425.316 & 233 & & & \\
\hline \multirow{3}{*}{$\begin{array}{l}\text { Adequate common facilities } \\
\text { are provided to encourage } \\
\text { social interaction }\end{array}$} & Between Groups & 101.499 & 2 & 50.750 & 29.254 & .000 \\
\hline & Within Groups & 400.740 & 231 & 1.735 & & \\
\hline & Total & 502.239 & 233 & & & \\
\hline \multirow{3}{*}{$\begin{array}{c}\text { I feel normal when being } \\
\text { watched by guard }\end{array}$} & Between Groups & 6.051 & 2 & 3.025 & 1.405 & .247 \\
\hline & Within Groups & 493.048 & 229 & 2.153 & & \\
\hline & Total & 499.099 & 231 & & & \\
\hline \multirow{3}{*}{$\begin{array}{c}\text { The visual characteristics of } \\
\text { the facility is pleasing }\end{array}$} & Between Groups & 12.170 & 2 & 6.085 & 4.186 & .016 \\
\hline & Within Groups & 332.860 & 229 & 1.454 & & \\
\hline & Total & 345.030 & 231 & & & \\
\hline \multirow{3}{*}{$\begin{array}{c}\text { The interior colours are } \\
\text { pleasing }\end{array}$} & Between Groups & .249 & 2 & .124 & .073 & .930 \\
\hline & Within Groups & 391.502 & 230 & 1.702 & & \\
\hline & Total & 391.751 & 232 & & & \\
\hline \multirow{3}{*}{$\begin{array}{c}\text { Design promotes image of } \\
\text { incarceration }\end{array}$} & Between Groups & 3.679 & 2 & 1.839 & 1.273 & .282 \\
\hline & Within Groups & 340.974 & 236 & 1.445 & & \\
\hline & Total & 344.653 & 238 & & & \\
\hline
\end{tabular}

\section{DISCUSSION}

Previous studies such as Gendreau and Keyes (2001) have emphasized the need for juvenile rehabilitation centres to be integrated to the surrounding community in order not to create a disconnection between the young offenders and the society to which they will return. In contrast to this, visual survey result shows that the three studied juvenile rehabilitation centres in Nigeria were located away from the surrounding communities and fenced with block walls, 
allowing no visual contact with the outside. The effect of this is reflected in the questionnaire survey result which shows that majority of the young offenders $(79.50 \%)$ in these centres agreed that the location makes them feel isolated and incarcerated, with a mean score of 3.90. Also, ANOVA shows that this statement is true for the three juvenile rehabilitation centres (BTIK, BTII and KHRCJ) with a $\mathrm{p}$ value of $0.663>0.05$, which means that there is no significant difference between respondents at the three juvenile rehabilitation centres. This means that location and site planning is a major problem in the Juvenile rehabilitation centres in Nigeria and should be given proper consideration in the design of such centres in the future.

With regards to spatial organisation, studies have emphasized the importance for juvenile rehabilitation centre to be organized around spaces that allows for surveillance and the grouping of activities around functional clusters or linear sequence (Waid and Clement, 2001; Mcmillen and JPI, 2005). The visual survey result shows that one of the three juvenile rehabilitation centres were laid out with a central courtyard around which all other facilities and activities revolve. The others were dispersed and in clusters of related facilities. While the central courtyard approach has the advantage of supervision and better participation, the other allows for better zoning and access control.

Questionnaire response shows that majority of the respondents from BTIK $(58.66 \%)$ and BTII $(65.83 \%)$ agreed with the statement that the layout of facilities and circulation system encourages active participation. This is attributable to the clustered layout within the centres which link facilities within short distances. However, only $10 \%$ of the respondents from KHRCJ agreed with the statement. This is likely due to the dispersed nature of facilities within the centre, and the fact that the clusters were separated walled to restrict access. This difference is reflected in the result of ANOVA which shows that there was significant difference on the statements that the layout of facility encourages active participation in activities, $p=0.008$. This means that there is no consensus on the spatial organisation. While the spatial organisation at BTIK and BTII are perceived to be appropriate, that of KHRCJ requires much restructuring. The study further suggests that dispersed spatial organisation is not perceived as favourable by juveniles in the rehabilitation centres.

Satisfying needs through the provision of facilities which young offenders had access to before their incarceration, has been identified as a key factor in behavioural intervention in order to discourage idleness and promote healthy social interaction (Mcmillen and JPI, 2005; Jones, 2008). From the visual survey, it is evident that BTIK provided the widest variety of facilities. This is reflected in the questionnaire response in which $77.34 \%$ of respondents with a mean score of 4.04 agreed that sufficient sports and recreational facilities were provided, as against 51.895 and $30.00 \%$ at BTII and KHRCJ respectively. Also, the provision of mosques at BTIK and KHRCJ resulted in the perception that the presence of common facilities (day rooms, religious facilities) encourages healthy social interaction, with mean scores of 3.68 and 4.60. This is against a mean score of 2.50 at BTII where no mosque was provided. These differences are reflected in the result of ANOVA which shows that there is a significant difference on the statement that adequate sports and recreational facilities are provided, $\mathrm{p}=0.000$, and adequate common facilities are provided to encourage social interaction, $\mathrm{p}=0.000$. This means that there is no consensus on the provision of facilities across the three rehabilitation centres. The result shows the importance of variety of facilities in juvenile rehabilitation facilities and that religious facilities play a major role in satisfying the facility needs of inmates in such facilities.

While supervision and security is essential in juvenile rehabilitation centres, an effective design of the built environment should maximize freedom, mobility and flexibility (Marmot, 2002), minimise blind spots (Waid and Clements, 2001; Griffin and Hepburn, 2013), reduce the need for direct supervision and promote unobtrusive supervision (Mcmillen and JPI, 2005). The layout of BTIK is around a central court which promotes unobtrusive supervision, while the layout of KHRCJ is in different clusters but with open spaces, but BTII 
is in a closely packed cluster which calls for direct supervision. Questionnaire responses showed that only $41.84 \%$ of the total respondents across the three rehabilitation centres, with a mean score of 2.76 felt okay being watched by security guards. ANOVA result shows that there is significant difference between respondents at the three juvenile rehabilitation centres on the statement that they felt normal when being watched by guard, $p=0.247$. This means that the design of the juvenile rehabilitation centres should encourage unobtrusive supervision as recommended by Mcmillen and JPI, (2005).

Previous studies have established connections between the visual characteristics of juvenile rehabilitation centres and the outcome of the rehabilitation process and recommended the elimination of the stereotypical intimidating image of punishment and (Atlas and Dunham, 1990), familiar and comfortable surroundings (Mcmillen and JPI, 2005), inspiring architectural character, with the use of normalized materials, soft texture and colours (Crowe, 2000). Also, the detention of young offenders in facilities with the semblance of prisons should be discouraged (Holman and Ziedenberg, 2006), through appropriate design that are responsive to the young offenders' perceptions and behaviours (McMillen and JPI, 2005). In contrast to this, the three rehabilitation centres are fenced with solid blocks and painted with the colours of the Nigerian Prisons Service, thereby promoting the image of incarceration. The buildings at the three rehabilitation centres also have the semblance of class room blocks with little or no landscaping to enhance their aesthetics. Despite these, $43.51 \%$ of respondents perceived the built environment as pleasing, with a mean score of 2.95. Based on international and local requirements for juvenile rehabilitation centres, and the visual survey, there appears to be high level of deficit in the facilities and character of these centres, and a low level of correlation between the perception of the researcher who is an outsider and the perception of the young offenders themselves.

This may be attributed to the fact that most of the young offenders were probably from less privileged families, and lived in environments that were not much better. However, $68.20 \%$ of respondents with a mean score of 3.71 perceived the design of the rehabilitation centres as promoting the image of incarceration and contributing to depression. ANOVA result shows that there is significant difference on the statement that the visual characteristics of the facility is pleasing, $\mathrm{p}=0.016$. This means that there is a need to improve the visual characteristics of the juvenile rehabilitation centres in order to enhance the rehabilitation centres. This should however be based on familiar architectural characteristics as recommended by Mcmillen and JPI (2005).

The above discussion shows that the juveniles in the rehabilitation centres are aware of their built environment and its impact on them. Aspects of the built environment which were not in conformity with requirements received corresponding negative perception. The centres were largely positively perceived with respect to the provision for sporting, recreation, religious and other common facilities. Aspects relating to the character and image of the centres such as location, landscape, visual character, interior colours and visual communication with outdoors, were perceived negatively by the juveniles in most of the centres. This suggests that the centres image portrays more of incarceration rather than reformation. This image needs to be changed in order to give the juvenile rehabilitation centres in Nigeria a more positive outlook which will in turn culminate in more positive outcomes for the young offenders

\section{CONCLUSION}

Though the visual survey of the selected juvenile rehabilitation centres in Nigeria showed that there was a high level of deficit in the provision of amenities when compared with local and international standards, the questionnaire survey result shows that majority of the young offenders had positive perception of the level of amenities provided. This is attributable to the background of the young offenders and the environments in which they lived before being taken into custody. This shows that the perception of such facilities varies from one young offender to another or among groups of offenders, and the design of such facilities must take these peculiarities into consideration. Aspects relating to the image and visual character of the centres were perceived 
negatively by majority of the respondents. This image needs to be changed in order to give the juvenile rehabilitation centres in Nigeria a more positive outlook which will in turn culminate in more positive outcomes for the young offenders. Based on the above, further research is recommended to establish the relationships between the environment in which the young offenders lived before their incarceration and their disposition to the built environment of juvenile rehabilitation facilities.

\section{REFERENCES}

Adetula, G. A., Adetula. A., and Fatusin, A. F. (2010), The Prison Subsystem Culture: Its Attitudinal Effects on Operatives, Convicts and the Free Society, Ife Psychologia, 18(1): 232-251.

Akinci, G. (2012), The Purposes and Meanings of Surveillance: A Case Study in a Shopping Mall in Ankara, Turkey, Security Journal, 28, 39-53.

Amnesty International (2008), Nigeria: Prisoners' Rights Systematically Flouted. AI Index: AFR 44/001/2008. Amnesty International Publications, London.

Atlas, R. I., and Dunham, R. G. (1990), Changes in Prison Facilities as a Function of Correction Philosophy, In Murphy, J. W. and J. E. Dison, J. E. (Eds.), Are Prisons any Better? Twenty Years of Correctional Reform, Sage, Newburg Park CA. pp 43-59 (1990)

Burrell, S. (2013), Trauma and the Environment of Care in Juvenile Institutions, The National Child Traumatic Stress Network, Retrieved from www.njjn.org/.../NCTSN_trauma-andenvironment-of-juvenile-care-insti...

Choutka, C., Doloughty, P., and Zirkel, P. (2004), The "Discrete Trials" of Applied Behaviour Analysis for Children with Autism, Journal of Special Education, 38, 95-103.

Crowe, T. (2000), Crime Prevention through Environmental Design: Applications of Architectural Design and Space Management Concepts, ButterworthHeinemann, Boston

Cummings, N. G. (2012), Fostering Sustainable Behaviour through Design: A Study of
Social, Psychological and Physical Influences of the Built Environment, Masters Thesis, University of Massachusetts

Duda, M., Utley, C. (2004), Positive Behaviour Support for At-Risk Students: Promoting Social Competence in At-Risk Culturally Diverse Learners in Urban Schools, Multiple Voices for Ethnically Diverse Learners, 8(1), 128-143

Eiseman, L. (2006), Colour: Messages and Meanings - A Pantone Colour Resource, Hand Books Press, Gloucester MA

Gendreau, P. and Keyes, D. (2001), Making Prisons Safer and More Humane Environments, Canadian Journal of Criminology, 43:123-130

Grant, E. M. (2014),Facilities for Australian Indigenous Prisoners after the Royal Commission into Aboriginal Deaths in Custody, Australian Indigenous Law Review, 77(1):47-55, Retrieved from http://www.ilc.unsw.edu.au/publications/v olume-17-number-1

Green, A. E., Gesten, E. L., Greenwald, M. A. and Salcedo, O. (2008), Predicting Delinquency in Adolescence and Young Adulthood: A Longitudinal Analysis of Early Risk Factors, Youth Violence and Juvenile Justice, 6(4), 323-342

Griffin, M. L. and Hepburn, J. R. (2013), Inmate Misconduct and the Institutional Capacity for Control, Journal of Criminal Justice and Behaviour, 40(3): 270-288

Holman, B., and Ziedenberg, J. (2006), The Dangers of Detention: The Impact of Incarcerating Youth in Detention and Other Secure Facilities, A Justice Policy Institute Report, Retrieved from www.justicepolicy.org/images/.../0611_rep_dangersofdetention_jj.pdf

Hunte, M. (2006, March), A Qualitative Study of Delinquency and Achievement among Low Income Youth in Trinidad, A paper presented at the SALISES 7th Annual Conference, University of West Indies, Cave Hill, Barbados

Jones, K. (2008), Theory of Juvenile Delinquency: Why Young People Commit Crimes, Retrieved from www.associated content.com/popprint.sutml?

Idris, O. M. and Ejikeme, C. P. (2005), 
Community Participation and Involvement in the Correction of Juvenile Delinquencies in Nigeria, International Journal of Social and Policy Issues, 3(2), 27-32

Lane, L. K., Pierson, R. M., and Givner, C. C. (2004), Secondary Teachers' Views on Social Competence: Skills Essential for Success, the Journal of Special Education, 38 (3), 174-186

Laws of Federation of Nigeria (2004). Borstal institutions and Remand Centres, Act, Cap B11 LTN 2004.

Malekpour, M. (2007), Effects of Attachment on Early and Later Development, Journal of Developmental Disabilities, 53, 81-95

Mazumdar, S. (2000), Design Professionals and the Built Environment, In Knox, P. and Ozolins, P. (Eds.), People and the Built Environment, Wiley, Chichester. pp 157169.

McClure, W. R. and Bartuska, T. J. (2007), The Built Environment: A Collaborative Inquiry into Design and Planning, John Wiley and Sons, New Jersey

McMillen, M., and Justice Planners International (2005), Project Guide: Juvenile Facility Design, Native American and Alaskan Technical Assistance Project, Retrieved from www.nicic.org/pubs/2003/018443.pdf

Osuala, E. C. (2005). Introduction to research methodology. Onitsha: Africana-First Publishers Ltd.

Prison reforms: Panel's recommendations will be implemented (2006, November 15), New Nigerian Newspaper

Reaper, A., and Kamenev, A. (2004), Standards to Guide the Delivery of Services in Juvenile Justice Custodial Centres, Juvenile Justice Section, Community Care Division, the Victorian Government Department of Human Services, Melbourne, Victoria

Schubert, C. A., and Mulvey, E. P. (2013), Perceptions and Outcomes in Adolescent Confinement, MacArthur Foundation, Chicago, Retrieved from www.pathwaysstudy.pitt.edu/.../RPD\%20 Residen

Simoes, C., Matos, M. G., and Batista-Foguet, J. M., (2008), Juvenile Delinquency: Analysis of Risk and Protective Factors Using
Quantitative and Qualitative Methods, Cognition, Brain, Behaviour, an Interdisciplinary Journal, 7(4): 389-408

Tarolla, S. M., Wagner, E. F., Rabinowitz, J., and Tubman, J. G. (2002), Understanding and Treating Juvenile Offenders: A Review of Current Knowledge and Future Directions, Aggression and Violent Behaviour, 7(2):125-43

Tenibiaje, D. J. (2010), Counselling for Productive Employment of Prisons Inmate, European Journal of Educational Studies, 2(3), pp 193 - 202

United Nations (1990), United Nations Guidelines for the Prevention of Juvenile Delinquency (The Riyadh Guidelines), adopted and proclaimed by General Assembly resolution $45 / 112$ of 14 December 1990, Retrieved from http://www.unhchr.ch/html/menu3/b/h_co $\underline{\mathrm{mp} 47 . \mathrm{htm}}$

United Nations (2003), Juvenile Delinquency World Youth Report, 2003, United Nations, New York

Villanueva, M. R. (2006), Juvenile Delinquency, Manila: College of Criminology, Manilla

Waid, C. A., and Clements, C. B. (2001), Correctional Facility Design: Past, Present and Future, Correction Compendium, 26(11):1-29

Wener, R. E. (2012), The Environmental Psychology of Prisons and Jails: Creating Humane Spaces in Secure Settings, Cambridge University Press, Cambridge 